\title{
A SMART CITY MEGOLDÁSOK TECHNOLÓGIAI HÁTTERE ÉS FENNTARTHATÓ KOMPLEX MODELLJE
}

\section{THE TECHNOLOGICAL BACKGROUND AND SUSTAINABLE COMPLEX MODEL OF SMART CITY SOLUTIONS}

\author{
Jakab László', Sallai Gyula², Kovács Kálmán \\ 'egyetemi tanár, dékán, Budapesti Múszaki és Gazdaságtudományi Egyetem Villamosmérnöki és Informatikai Kar \\ jakab@ett.bme.hu \\ ${ }_{2}^{2}$ professor emeritus, Budapesti Müszaki és Gazdaságtudományi Egyetem Villamosmérnöki és Informatikai Kar \\ sallai@tmit.bme.hu \\ 3egyetemi docens, igazgató, Budapesti Műszaki és Gazdaságtudományi Egyetem Villamosmérnöki és Informatikai Kar \\ Egyesült Innovációs és Tudásközpont, kovacsk@eit.bme.hu
}

\section{ÖSSZEFOGLALÁS}

Tisztázni szükséges, hogy a közel és a nem túl távoli jövőben milyen városfejlesztési kihívásokkal kell szembenéznünk, és azt is, hogy a digitális vagy az információs és kommunikációs technológiák (ICT) segítségével a felmerülő kérdésekre és problémákra milyen válaszokat tudunk adni. Az okosváros-megoldások (Smart City Solutions) jellemzői közé tartozik, hogy élhetőbb, környezettudatos, közösségi részvételt tartalmazó és gazdaságilag önfenntartó megoldásokban gondolkozzunk, ilyen válaszokat keressünk. A rendszertechnikai elvárások, alapelvek, megközelítések és platformok közé kell sorolnunk az adatvezérelt, integrált szemléletet és a jövő, illetve a következő generációs internet-technológiák alkalmazását. Figyelembe kell vennünk a már létező okosváros-alkalmazásokat és -kulcsterületeket, a technológiai lehetőségeket és az ezekkel járó fenyegetések új hullámát is. A cél lehet egy "smart” város, "smart” gyártás és „smart” internet ökoszisztéma megalkotása. Jelen dolgozatunk ezeket a kérdéseket érinti.

\section{ABSTRACT}

It is necessary to clarify the urban challenges we face in the near and not too distant future, and the responses we can give to emerging issues and problems with digital, or information and communication technologies (ICT). The characteristics of Smart City Solutions include seeking more liveable, environmental-aware, community-based and economically self-sustaining solutions and responses. We need to add the data-driven, integrated approach and the use of Future and Next Generation Internet technologies to the system requirements, principles, approaches and platforms. We must take into account the already existing smart city applications and key areas, technological opportunities, and the new wave of accompanying threats. The aim may be the creation of a 'smart' city, 'smart' manufacturing and a 'smart' internet ecosystem. In our present paper, we briefly address these issues. 
Kulcsszavak: okos város, ICT, következő generációs internet, smart megoldások, City-Pulse

Keywords: Smart City, ICT, Next Generation Internet, smart solutions, City-Pulse

\section{BEVEZETÉS}

A 21. században számolnunk kell azzal, hogy már most is az EU népességének mintegy $70 \%$-a él városias területen. A városokban állítják elő az EU GDP-jének több mint kétharmadát, a digitális technológia dinamikus fejlődése áthatja az élet szinte minden területét. Emellett viszont markánsan jelentkeznek tartós, összetett problémák, összefonódó környezeti, gazdasági, társadalmi és kulturális kihívások. Általános cél, hogy legyen a város barátságos, élhetőbb, szerethetőbb, vonzóbb. Olyan fejlesztésekre, megoldásokra van szükség, amelyektől a lakók jobban érzik magukat, amelyek segítenek a település problémáinak megoldásában.

\section{OKOSVÁROSOK ÉS AZ ICT-LEHETŐSÉGEK}

Napjainkra képesek lehetünk a kihívások megválaszolására a digitális technológia révén, az információs és kommunikációs technológia (ICT) segítségével, azon belül különösen az okos, internetalapú megoldások alkalmazásával.

Az ICT segít a célok gazdaságos, rugalmas és skálázható megvalósításában, a város valós idejü monitorozásában és az adatok feldolgozásában, a közösséggel való kapcsolattartásban (ösztönzés, javaslatgyüjtés, egyeztetés), a kihívásokra valós idejü válaszok megfogalmazásában, a megszerzett tudás hasznosításában, hatékonyabb szervezési, illetve müszaki megoldások kialakításában.

Az ICT, azon belül is az internetalapú megoldások megjelennek az önkormányzati munkában, az energiaellátásban, a közlekedésben, az oktatásban, az egészségügyben, a szociális ellátásban, az ivóvíz- és szennyvízszolgáltatásban, a környezet figyelésében, a törvénykezésben, iparban, kereskedelemben, mezögazdaságban, átalakítják az emberi kapcsolatokat (közösségi média), integrálják a hagyományos és elektronikus médiát, és elérhetővé teszik a világ tudását egy okostelefon révén. Az Európa 2020 program víziója egy intelligens, inkluzív és fenntartható társadalom, amelynek megvalósítása, stratégiája és programjai az ICT-megoldások sokoldalú és integrált alkalmazásán alapulnak (1. ábra).

Rövid távon is számolnunk kell a hálózatosodás fokozódásával, a gépek közötti kommunikáció (M2M, Ipar 4.0) elterjedésével, a dolgok/tárgyak internete (IoT, Internet of Things) gyors kialakulásával és általánossá válásával (2. ábra). 


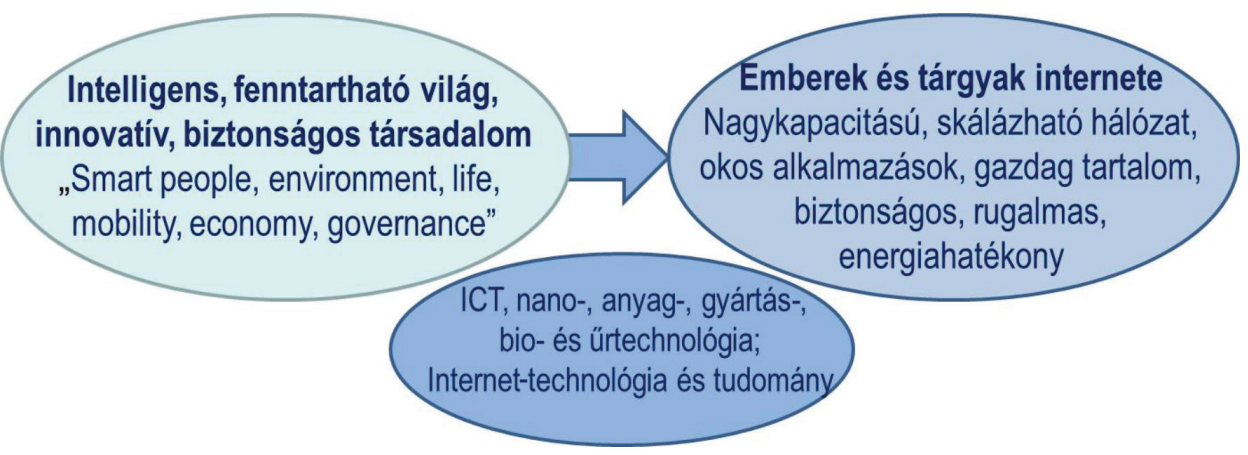

1. ábra. Az Európa 2020 program víziója

(Saját szerkesztés)

A szükséges vezeték nélküli, akár nagysebességü, akár kis energiaigényü vagy kis fogyasztású rendszerek kidolgozása, fejlesztése nagy erőkkel folyik.

Lényeges, hogy az ICT-megoldások bevezetése élhetőbb várost eredményezzen, a helyi közösség számára pozitív hatású legyen (Smart City and Community). A fontosabb rendszertechnikai elemek ennek megfelelően a valós idejü adatgyüjtés, amelyhez különféle szenzorokra van szükségünk városszerte, az

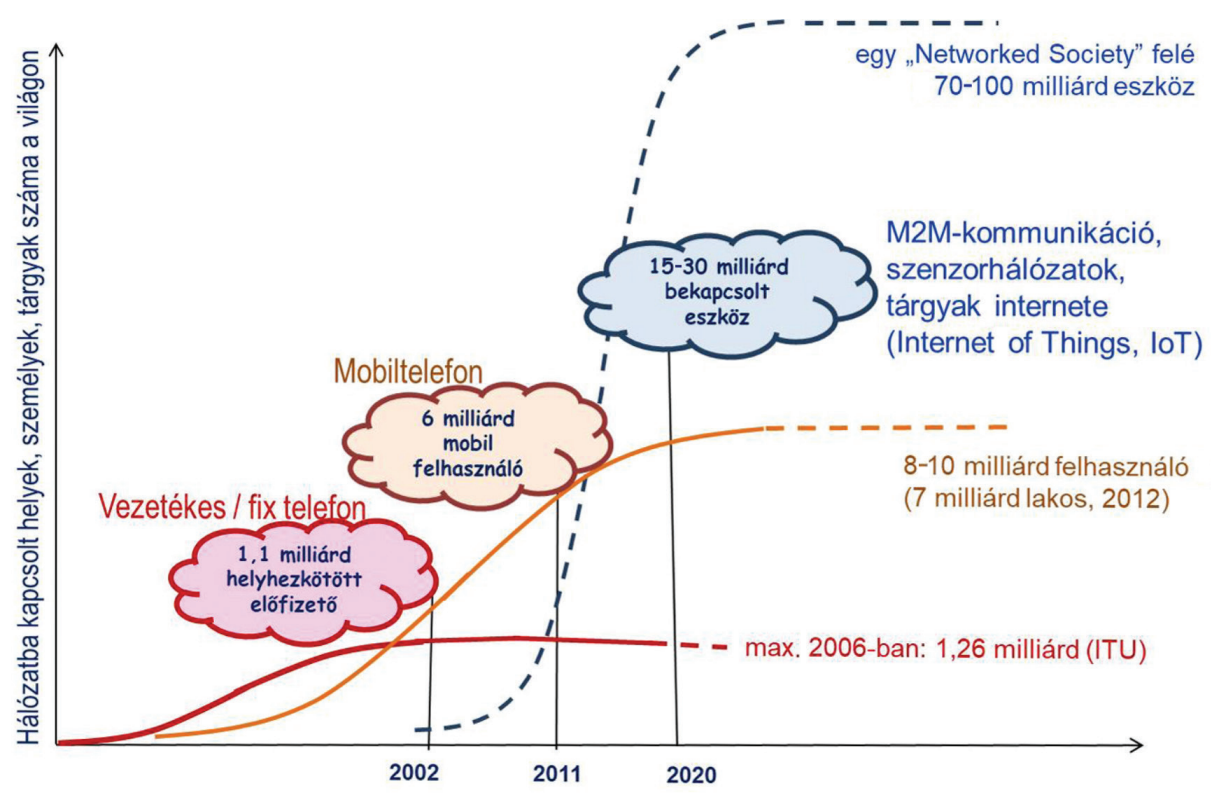

2. ábra. A hálózatosodás fokozódása

(Saját szerkesztés) 
adatok analízise a riasztások, elörejelzések, tervezési információk érdekében és az infrastruktúrák vezérlése a hatékonyság, adaptivitás és a biztonság eléréséhez, javításához. Az okosvárosi alkalmazások a szolgáltatások bővítésével növelhetik a városlakók kényelmét, segítik tájékozódásukat, és a közösségi részvételt (e-participation, közösségi oldalak). A nagysebességű internethálózat, amellyel jó elérhetőség, magas minőség és alacsony ár is együtt jár, az 5G, az ötödik generációs vezeték nélküli technológiák segítségével képességeiben jelentősen bővülhet (kapacitás, megbízhatóság, szuper-valós idejü válaszidő stb.).

\section{ÚJ MEGKÖZELIITÉSEK}

Az okosváros-technológiák, Smart City-megoldások általános alapelve az integrált szemlélet. Ezért a jövö/következő generációs internet-technológiákra (FI/ NGI) alapozva többcélú eszközökre, szoftvermegoldásokra van szükségünk.

A jelenlegi kutatás-fejlesztések előterében a szenzorok és hálózatba kapcsolásuk, az Internet of Things (IoT) megoldások és kiberfizikai rendszerek (CPS) fejlesztése, az adattudományi módszerek (adatelemzés, adatbányászat, Big Data) felhasználása vannak. A térinformatika (GIS), a felhőszolgáltatások (cloud computing \& networking) és a hálózatvirtualizáció (NFV/SDN) ezt támogathatják. A mesterséges intelligencia, a kiterjesztett és virtuálisvalóság-technológiák (AR/ VR) új lehetőségeket nyitnak meg, az internetbiztonságnak pedig a magánszféra védelmét is szolgálnia kell.

Az okosváros-platformok kidolgozása során a vertikális helyett horizontális megközelítést kell alkalmaznunk (3. ábra). Jelenleg általában az „egy probléma - egy megoldás" modellben gondolkodunk a specifikus technoló-

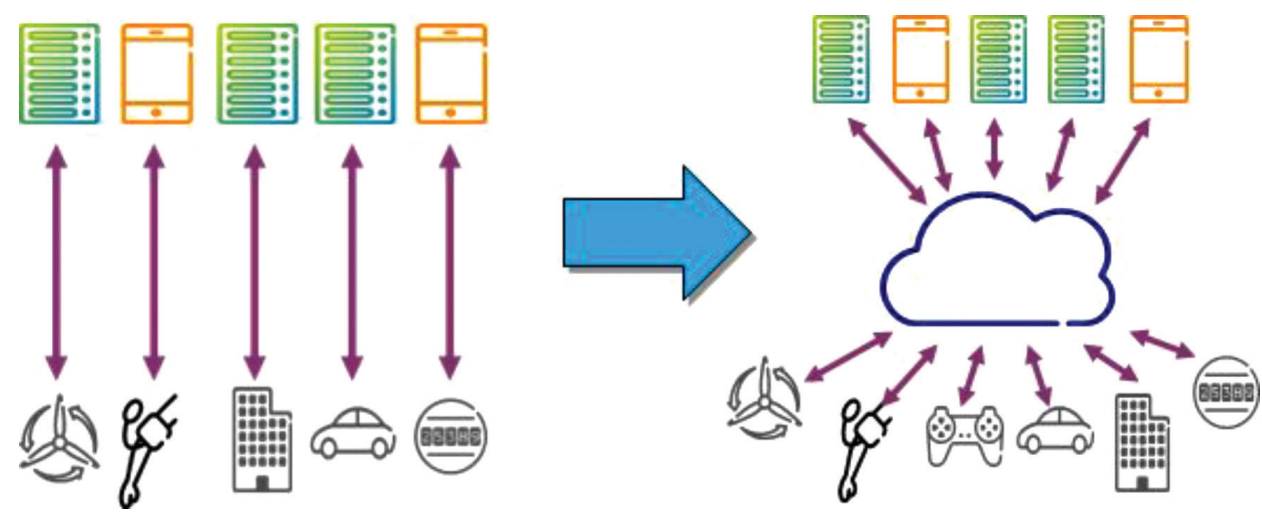

3. ábra. A vertikális és horizontális megközelítés összehasonlítása

(Saját szerkesztés) 
gia- és adatmegosztás nem jellemző. A jövőben az összetett problémák hatékonyabb, okosabb megoldása érdekében többcélú eszközöket alkalmazunk, az internet-technológiák, a közös adatplatformok (felhőben), az adatanalízis eredményeinek megosztása adatvezérelt, integrált (cross-domain) megoldásokhoz vezetnek.

\section{NAGY DIGITÁLIS PLATFORM-VÁLLALKOZÁSOK}

Ha globálisan nézzük a jelenlegi helyzetet, akkor azt látjuk, hogy nagy digitális platform-vállalkozások jöttek létre. Például a tranzakciók számában vezetők között olyanokat találunk, mint a Netflix, az Uber, az Airbnb, a PayPal vagy a Yahoo. Érdekes, hogy az Uber úgy a világ legnagyobb taxivállalkozása, hogy egyetlen autója sincsen. Az Airbnb a világ legnagyobb szállodai szolgáltatója, pedig egyetlen szálloda, ingatlan sincs a tulajdonában. A leginnovatívabb cégek az Oracle, a Microsoft, az Intel, a legnagyobb integrált rendszerek pedig a világon a Facebook, az Amazon, az Apple, a Google és az Alibaba (4. ábra). A Facebooknak több felhasználója van, mint Kína vagy India teljes lakossága, de a YouTube is az Egyesült Államok lakosságának háromszorosát is meghaladó felhasználói számot ért már el. Ebben a globalizációban erőteljes és domináns szerep jut Észak-Amerikának és Ázsiának. Európa alig van jelen a világtérképen, és ebben a sorsban Dél- és Latin-Amerikával osztozik.

\section{DIGITAL WORLD = GLOBAL DIGITAL PLATFORM}

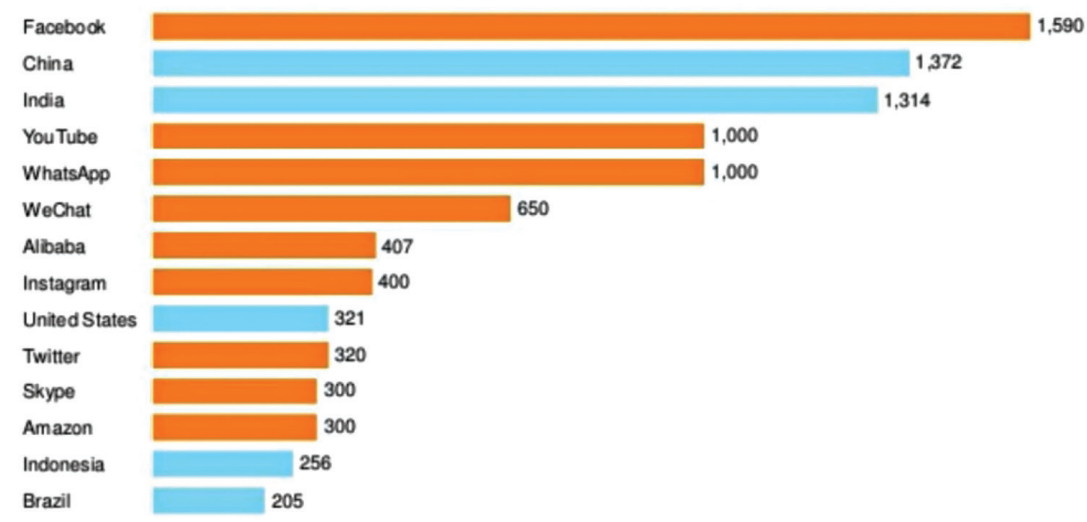

SOURCE: Facebook; Twitter; Aibaba; Fortune; Statsta; Population Reference Bureau; McKinsey Global Instihute analysis McKinsey 8 Company

4. ábra. A legnagyobb globális digitális platformok és a legnépesebb országok (W. Jonker, CEO, EIT Digital, March 21, 2017, Delivering Europe's Digital Transformation) 
Ebben a versenyben Európa is keresi a megoldásokat. A City-Pulse EU FP7es projekt éppen az alkalmazások sokaságára koncentrál egy közös platformon. Az emberek hagyományos internete és a tárgyak internete révén gyüjtött adatok tömegének analíziséből a különféle alkalmazások igény szerint merítenek, a hozzáférés jogosultságának feltétele mellett (5. ábra).

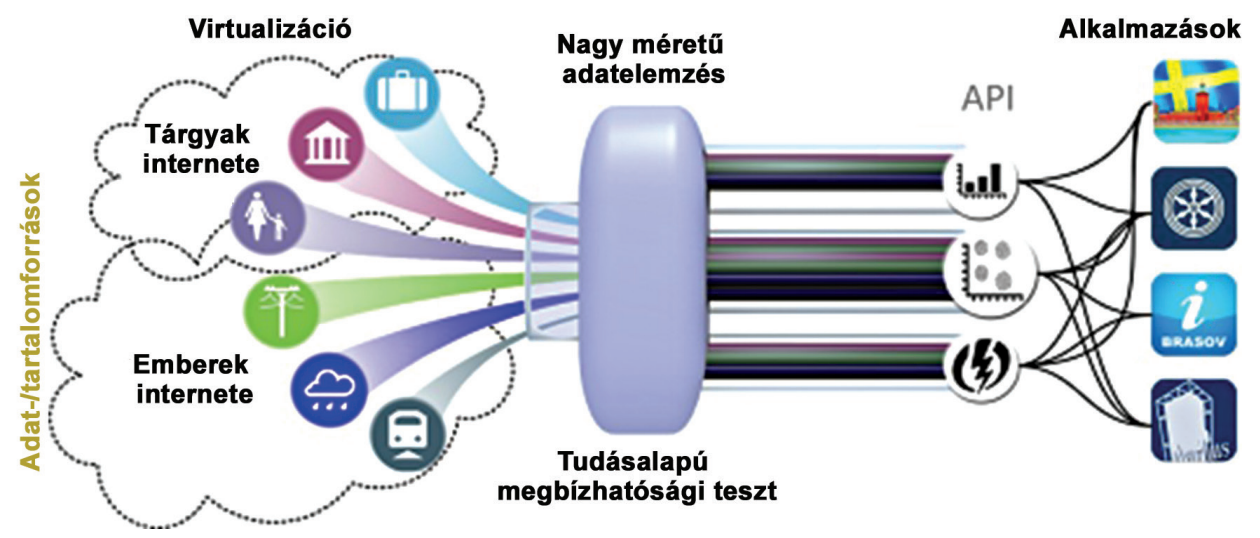

5. ábra. A City-Pulse kutatási projekt modellje

(CITY-PULSE: Real-Time IoT Stream Processing and Large-scale Data Analytics for Smart City Applications. FP-7 Contract Number: CNECT-ICT-609035, 2013-2016. http://www.ict-citypulse.eu)

A várost és környezetét ökoszisztémaként, integráltan kell kezelnünk, és tudatosan kell hasznosítanunk a különböző civilizációs és természeti körforgásokat. Ez többféle rendszerszerü megközelítést igényel, amelyek a természeti és környezeti szempontokat, az újrahasznosítást, a megújuló energiákat egyaránt hangsúlyosan kezelik. Ilyenek a circular economy, blue economy, zöld infrastruktúra, nature-based city (a természet fenntartható használata) és a bölcsőtől bölcsőig tervezés (C2C, regeneratív tervezés). Vannak és hozzáférhetők ICT-t alkalmazó nemzetközi smart sustainable cities ajánlások (SSC, ITU-T Y.4000 Recommendation, 2016) a természet és a városi infrastruktúra integrálásához.

Ahhoz, hogy érzékeljük, mekkora és milyen lehetőségek vannak a Smart City alkalmazások fejlesztésében, a 6. ábra nyújt segítséget. Ezen alkalmazások nagy része már ma is hozzáférhető, gondoljunk a különböző ,,play” áruházakban található mobil telefonalkalmazások nagy számára vagy a taxitársaságok és a tömegközlekedési szolgáltatók internetes vagy akár városi szolgáltatásaira. Az élenjáró alkalmazási területek a smart közlekedés és az autonóm jármüvek, az eHealthcare, „orvoslás infokommal” (VR-rehabilitáció, digitális fogászat), az e-közigazgatás, e-oktatás. 


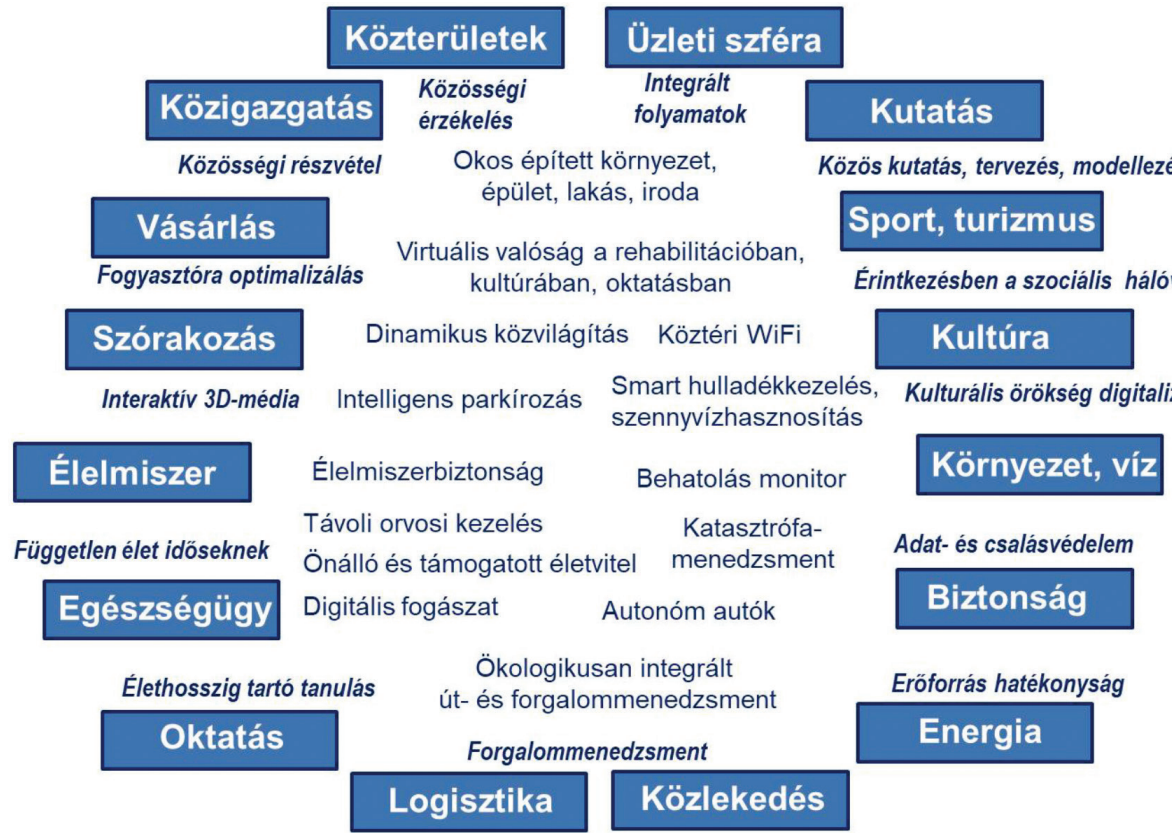

6. ábra. Smart City alkalmazások területei és példái

(Saját szerkesztés)

\section{OKOSVÁROSOKÉS A KÖRNYEZET}

Az okosváros-koncepciók meghatározó eleme a környezetbarát gazdálkodás, a megújuló energiafelhasználás arányának növelése és a városi környezeti, illetve zajterhelés csökkentése. Ebben is nagyok a lehetőségek és Magyarország vonatkozásában is nagy tartalékok vannak. A villamosenergia-fogyasztás tekintetében, például a hazai minimális és maximális nyári bruttó rendszerterhelés 2015 . július és augusztus hónapban $4300 \mathrm{MW}$ és $6400 \mathrm{MW}$ között mozgott. A hazai erőmü-összetétel és -kapacitás ugyanebben az évben, hasadóanyagra $2000 \mathrm{MW}$, fosszilis energiára $5840 \mathrm{MW}$, megújuló energiára $700 \mathrm{MW}$ volt. Ez összesen több mint $8500 \mathrm{MW}$, vagyis jelentősen meghaladta a felhasználói igényt. Ennek ellenére a hazai fogyasztásnak nagyjából 3500 MW feletti részét importból fedeztük a környező országokból, mivel az áram olcsó. A hazai erőmüvek közül leginkább csak a nagyok (Paks, Mátraalja) üzemeltek és üzemelnek ma is folyamatosan.

Ezek alapján eléggé kézenfekvő, hogy elektromos autózásban, tágabb értelemben véve e-mobilitásban is gondolkodjunk. A környezetszennyezö, belső égésü motorral közlekedő járművek lecserélése elektromos, nullaemissziós járművekre 
a városok lokális környezeti szennyezését csökkenti, még akkor is, ha az elektromos energiát a környező országokból származó, környezetszennyező széntüzelésű erőmüvekből kapjuk.

Néhány további szemponttal azonban, legalábbis müszaki szempontból mindenképpen számolnunk kell. Az energiahordozók energiatároló képessége eléggé különbözö. A jelenleg legjobbnak tartott Li-ion akkumulátorokban fajlagosan, tömegre vetítve $100 \mathrm{Wh} / \mathrm{kg}$, térfogatra vetítve $300 \mathrm{Wh} /$ liter energia tárolható, amelyek legalábbis ebből a szempontból kevéssé versenyképesek a dízelolaj 10000 Wh/kg vagy $10000 \mathrm{Wh} /$ liter kapacitásával. Vegyük észre, hogy a különbség közel két nagyságrend, a dízelolaj javára. Szerencsére a villanymotorok hatásfoka akár $96 \%$ is lehet, a dízelmotoroké pedig ennél kevesebb: bár ma már a 40\%-ot is elérheti, de a gyakorlatban, normál üzemben ez az érték inkább a $25 \%$ köré esik. Így 1 liter hagyományos üzemanyag nagyjából 20-25 kg Li-ion akkumulátorral váltható ki. Ettől aztán az elektromos járművek tömege nagy, hatótávolsága pedig kicsi lesz.

\section{TECHNOLÓGIAI LEHETŐSÉGEK ÉS FENYEGETÉSEK ÚJ HULLÁMA}

Exponenciális ütemủ technológiai innovációkkal kell számolnunk a szenzorok, szenzorhálózatok, IoT területén. Vannak lehetőségek a nanotechnológiában, a 3D-nyomtatás és -szkennelés már nem csak kutatóintézetekben érhető el. A kiberfizikai rendszerek, intelligens robotok, drónok megjelentek a mindennapi életünkben, míg a platformok és alkalmazások kombinatorikus értékteremtéssel járulnak hozzá a fejlődéshez. Az üzleti modellek innovációja a játékszabályok változását hozhatja. Az információs hadviselés pedig megjelent a napi hírekben.

A jövőben számolnunk kell a gyors, internetalapú technológiai áttörésekkel. A közösségi érzékeléssel és a közösségi médiával kiszélesedik a tartalom-elöállítók köre. Az adatvezérelt megoldások áthatják életünk minden területét. A legfiatalabb generáció ebben nő fel, integrálódva a smart internettel, a következmény a Cognitive Entity Generation. Technológiai korszakváltás jön a termelésben (Smart Factory/Manufacturing, okosgyár/termelés, Ipar 4.0), kiberfizikai rendszereken, CPS- (Cyber-Physical Systems) alapú, az egész értékláncot átfogó ipari rendszerek valósulnak meg a terméktervezéstől a gyártástervezésen és gyártáson át a végtermék forgalmazásáig és utógondozásáig. Ugyanakkor váratlan üzleti bukások történtek és lehetségesek a digitális környezet hatásának alábecsülése miatt, szükséges a digitális megközelítésü stratégia. 


\section{SMART CITY-ÉS SMART FACTORY-ÖKOSZISZTÉMÁK}

Az ember és a digitális technológia összefonódásának várható bekövetkezését, egy digitális ökoszisztéma kialakulását a World Economic Forum már 2007ben megfogalmazta. Ma már inkább internet-ökoszisztémáról (sőt Smart Internet-ökoszisztémáról) beszélünk, amely a technológiát, a társadalmi beágyazottságot és a globális hálózatos megjelenést (és az okos megoldásokat) is kifejezi. Az átfogó (smart) internet-ökoszisztéma részeként már sokféle ökoszisztémát is értelmeznek (például IoT-ökoszisztéma). Prominens példa az ember és az internet mind szorosabb összefonódására a Smart City-ökoszisztéma létrejötte. Ebből a szempontból a Smart City kulcsterületeket és az alkalmazásokat szimbolikusan az alábbiak szerint csoportosíthatjuk:

- okos-energiatárolás, -felhasználás, -menedzsment, megújuló energiák;

- épített környezet, iroda, lakás, hulladék- és szennyvízkezelés, ivóvízellátás;

- életvitel: egészségügy, foglalkoztatás, oktatás, kultúra, sport, vásárlás, média, személyes szolgáltatások;

- okosjármüvek, közlekedési pályák, parkírozás, forgalomirányítás;

- városvezetés, városfejlesztés, vállalkozásfejlesztés, közösségi részvétel;

- a smart hátteret nyújtó infokommunikációs rendszerek és hálózatok.

Ez a hat terület, hatszögben elrendezve igen jól illeszkedik az integrált termelési rendszerek (Smart Factory, Ipar 4.0) hasonlóan képezhető kulcsterületeihez (7. ábra). A 8. ábra a smart ökoszisztéma internetes infrastruktúráját mint az okosvárosok és okosgyárak közös kiszolgálóját, smart hátterét szimbolizálja.

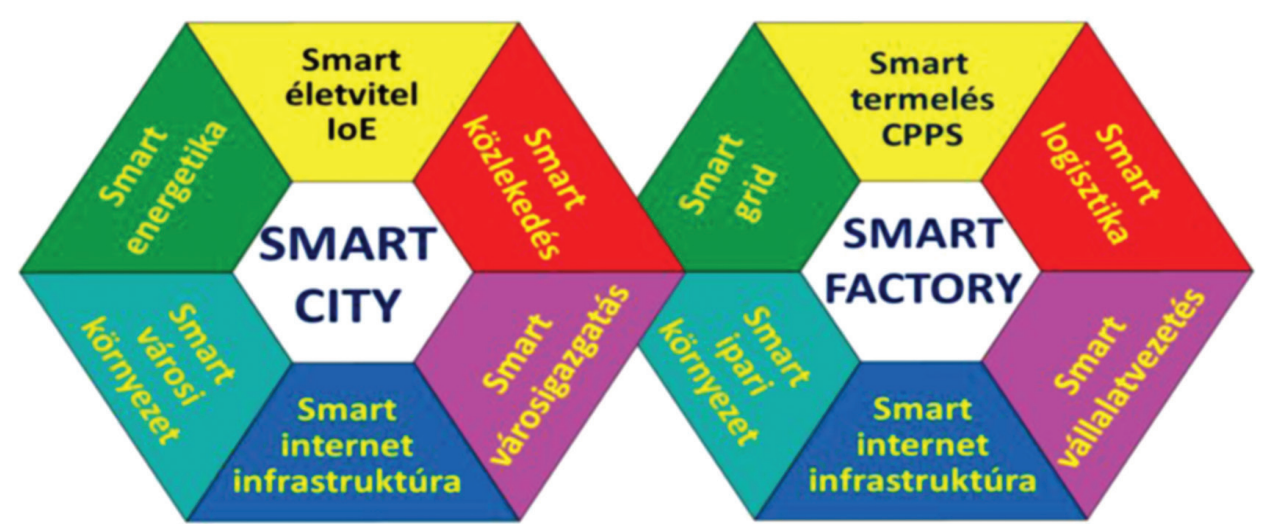

7. ábra. A Smart City- és Smart Factory-ökoszisztémák kulcsterületei (Saját szerkesztés) 


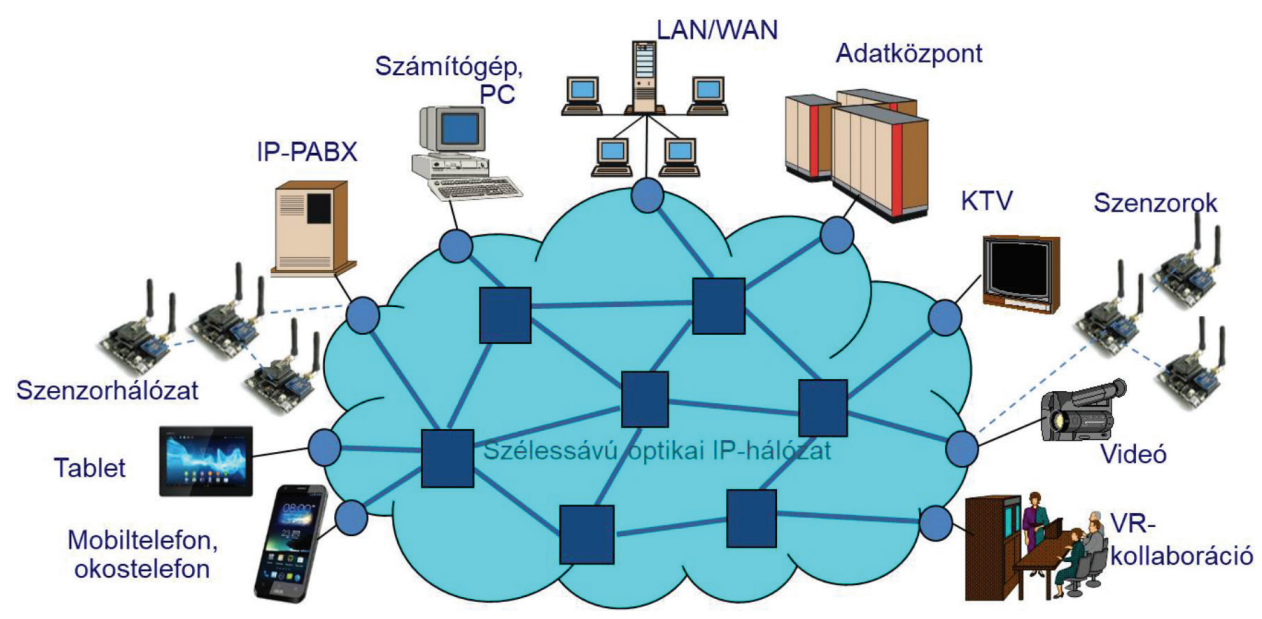

8. ábra. Smart internet infrastruktúra mint a Smart City- és Smart Factory-ökoszisztémák kiszolgálója

(Saját szerkesztés)

\section{ÖSSZEGZÉS}

Egy élhetőbb, barátságosabb várost szeretnénk, jobb életminőséggel és eröforrás-hasznosítással. Ebben segítségünkre van az információs és kommunikációs technológia (ICT), lehetővé téve a város és környezetének valós idejü monitorozását és az adatok feldolgozását, elősegítve valós idejủ válaszok megfogalmazását a kihívásokra, a közösséggel való kapcsolattartást, a tudás hasznosítását, hatékonyabb szervezési, illetve műszaki megoldások kialakítását, a fejlődés fenntarthatóságát. Ennek háttere és egyben következménye az ICT-technológiák gyors fejlődése, azon belül is az internet újabb generációinak kibontakozása.

A cikk a Környezeti kihívások - intelligens válaszok címü, az MTA Környezettudományi Elnöki Bizottság által szervezett nyilvános tudományos ülésen, 2017. július 14-én a Magyar Tudományos Akadémián elhangzott előadás alapján készült. A szerzők a kutatásaikat részben a Budapesti Müszaki és Gazdaságtudományi Egyetem és a Nemzeti Közszolgálati Egyetem közös „Okos város - okos közigazgatás: A technológia fejlődésének irányai és hatása" kutatóműhely keretében, az KÖFOP-2.1.2 „A jó kormányzást megalapozó közszolgálat-fejlesztés” projekt támogatásával végezték. 


\section{IRODALOM}

Bakonyi P. - Cinkler T. - Csoknyai T. et al., Sallai Gy. (szerk.) (2016): Smart City megoldások hat kulcsterületröl. Budapest: BME EIT, https://bit.ly/2zEeSPV

Jakab L. - Fehér G. - Vida R. (2018): Szenzorok és kommunikációs technológiáik, BME-NKE „Okos város - okos közigazgatás: A technológia fejlődésének irányai és hatása” kutatómühely (2017/162/BME-VIK), a KÖFOP-2.1.2 „A jó kormányzást megalapozó közszolgálat-fejlesztés” projekt keretében

Kovács K. (2018): Okos városok és az okos közigazgatás és városüzemeltetés európai és hazai környezetben. BME-NKE „Okos város - okos közigazgatás: A technológia fejlődésének irányai és hatása” kutatómühely (2017/162/BME-VIK), a KÖFOP-2.1.2 „A jó kormányzást megalapozó közszolgálat-fejlesztés" projekt keretében

Kovács K. - Bakonyi P. (2015): Future Internet and Smart Cities, avagy a jövö internete és az okos városok. Magyar Jövő Internet Konferencia, 2015, különszám. Híradástechnika, LXXI, 1,15-21.http://www.hte.hu/documents/10180/1727937/HT_2016-1_MJIK2015_2_Kovacs_Bakonyi.pdf

Sallai Gy. (2016): A jövő internet-kutatás célkitüzései és területei. Magyar Jövő Internet Konferencia 2015, különszám. Hiradástechnika, LXXI, 1, 3-14. http://www.hte.hu/documents/10180/1727937/HT_2016-1_MJIK2015_1_Sallai.pdf

Sallai Gy. (2018): Az okos város koncepció és az internet technológia. BME-NKE „Okos város - okos közigazgatás: A technológia fejlődésének irányai és hatása” kutatóműhely (2017/162/ BME-VIK), a KÖFOP-2.1.2 „A jó kormányzást megalapozó közszolgálat-fejlesztés” projekt keretében

World Economic Forum (2007): Digital Ecosystem - Convergence between IT, Telecoms, Media and Entertainment: Scenarios to 2015. (World Scenario Series), https://www.weforum.org/reports/digital-ecosystem-convergence-between-it-telecoms-media-and-entertainment-scenarios-2015 